\title{
Malatyas spejl - om Tyrkiets arabiske initiativ
}

\section{Lasse Ellegaard}

\section{Tyrkiet har indledt en veritabel diplomatisk offen- siv i den arabiske verden parallelt med støtte til Iran i atom-striden og forsoning med Armenien - men udenrigspolitisk succes går hånd $\mathrm{i}$ hånd med indre opløsning}

Tilfældet kan undertiden velsigne vinklen på en tekst, og tilfældet ville, at jeg for at par år siden i flyet fra Ankara til Istanbul sad ved siden af en dansker, der handler med fertilitets-teknologi. Han var på vej hjem fra Malatya i den østlige del af landet, hvor han havde instrueret en ny kunde i et indkøbt mikroskops finesser.

Som bevis på kundens taknemmelighed havde min sidemand fået en pose økologisk natur-slik, der fremstilles af gulerødder og kendes som cezerye og ifølge tyrkisk folklore er stærkt potens-fremmende. Så det faldt naturligt at spørge, hvad folk i Malatya skal med en fertilitetsklinik. Svaret var, at selvom man umiddelbart skulle tro, at tyrkerne er i stand til at formere sig ved egen hjælp, er markedet for reagensglasbørn stigende i Tyrkiet. Klinikken i Malatya er én af flere.

I modsætning til myten føder tyrkiske kvinder i gennemsnit under to børn - 1,96 for være nøjagtig - og eftersom fattige familier ofte får op til en halv snes, betyder det, at den voksende middelklasse akkurat som i Europa føder færre og færre. Dette plus den uhyre strikse adoptions-lovgivning gør fertilitetsmarkedet attraktivt også så langt ude i provinserne som Malatya.

Der var yderligere den morbide ironi i samtalen med den danske fertilitets-sælger, at Malatya netop i de dage var midtpunkt i en uhyggelig sag om grov mishandling på et af byens hjem for forældreløse og forladte børn mellem 0 og seks år, hvis 
rifter og mærker efter det uuddannede personales slag og skoldninger blev vist på tv.

Således er Malatya et sindbillede på Tyrkiet som tilstand - et land, der tilsyneladende knytter an til den vestlige modernitet, men mentalt er forblevet i det 19. århundredes overtro. Reagensglas-fertilitet og cezerye er således to sider af samme samfund, hvor globaliseringens nye økonomiske frihed har skabt en ny islamisk elite i det centrale Anatolien, der problemløst forbruger løs af den moderne (reagensglas-) teknologi samtidig med, at den kulturelt drømmer sig tilbage til den osmanniske imperie-arvs politiske og religiøse absolutisme med sultanat og kalifat.

Det er i den psykologiske sammenhæng man kan se Tyrkiets meget omtalte diplomatiske offensiv over for først og fremmest den arabiske verden, men også med målområder i Rusland, Centralasien, Iran, Kina, Indien og på det seneste tilmed Latinamerika.

Den islamisk rodfæstede flertalsregering under AKP (Adalet ve Kalkinma Partisi - Retfærd og Udviklings Partiet) har efter otte år ved magten en selvtillid, der kommer af positionen som Europas sjette-største økonomi (og verdens 17.-største), men også er et resultat af en gradvis udskiftning i den bureaukratiske elite, i retsvæsenet og i sikkerheds-apparatet, der nu er under 'islamisering' ikke ulig det politiske hamskifte de store byer (bortset fra Izmir) indledte, da AKP overtog kommunalbestyrelserne midt i 1990'erne.

\section{Kontakt til Hizbollah}

En eftermiddag i december 2009 drak jeg kaffe med Beirut-dagbladet Al-Akhbar's Tyrkiet-medarbejder Ernest Khoury, der kom lige fra en interview-aftale med Ersat Hürmüzlü, udenrigspolitisk seniorrådgiver for præsident Abdullah Gül.

Ernest var imponeret: "Du skulle have hørt ham tale arabisk", sagde han, "klassisk arabisk, ikke det flade talesprog, vi andre bruger i vores simple dialekter, men rigtigt arabisk - og fejlfrit."

- Hvad kunne han fortælle dig? ville jeg vide.

"Han var meget diplomatisk - det skal han jo være." Ernest kunne lige så godt have sagt: 'Ikke en dyt, og slet ikke noget, jeg ikke vidste på forhånd'. Men det sagde han ikke, idet alt for direkte tale er en vestlig uskik. I stedet sagde han: "Det vigtige ved hans Libanon-besøg er, at en tyrkisk diplomat for første gang er officielt inviteret af Hizbollah. Det er nyt."

Hizbollah har haft kontakt med AKP, siden det kom til magten ved valget i november 2002, men på et 'under bordet'-niveau, der ikke kun handlede om, at AKP har sunni-rødder, og at Hizbollah er shia-muslimsk, men især at Tyrkiet siden 
1996 har plejet militært samarbejde med Israel.

Den omstændighed, at kontakterne nu er fremme i medie-belysning, siger både noget om det ændrede arabiske syn på Tyrkiet, og om Ankaras ambitioner i mellemøst-politikken, der uanset alle forsikringer om det modsatte er et brud med den hidtidige udenrigspolitisk ensidige orientering mod vest.

I forholdet til den arabiske verden har Tyrkiet traditionelt været tynget af sin fortid som osmannisk kolonimagt og i det seneste årti af alliancen med Israel. Men med Gaza-krigen 2008-9 skete et åbenlyst skifte, da premierminister Erdogan udvandrede fra et tv-transmitteret skænderi med den israelske præsident, Shimon Peres, i Davos, hvor Erdogan påkaldte det sjette bud ('Du må ikke slå ihjel) og kaldte israelerne for 'barbariske'.

Med sin udvandring gjorde Erdogan det klart, at det tyrkisk-israelske samarbejde vil ophøre inden for overskuelig tid. Det næste signal om forværring af relationerne kom, da udenrigsminister Ahmet Davutoglu besøgte Israel i september og fik blankt nej til et ønske om at besøge Gaza, og endnu et brud var Tyrkiets aflysning af en fælles militærøvelse senere samme år med hele to begrundelser: at de deltagende israelske kampfly havde bombet civile i Gaza, og at Israel havde undladt at levere bestilte og betalte militære droner til Tyrkiet.

\section{Forbedret forhold til Syrien}

Aqqad-huset, adressen på Det Danske Institut i Damaskus' gamle by, er bygget til arabisk samtalekultur. Receptionsrummets brede stenbænke er designet i en tidsalder, hvor skrædderstilling var den foretrukne sidde-måde, hvilket gør det til en pine for knæ og ryg at gennemføre to dages intensiv konference-aktivitet.

Men det var hvad to snese akademikere og mediefolk gjorde i november, da de mødtes for at tale om 'Tyrkiet og den arabiske verden'.

Frygten for gigt fordampede i debatten om de politiske og diplomatiske herresving, der har gjort det hidtil så NATO- og EU-forhippede Tyrkiet til en magtfaktor, en sunni-islamisk 'storebror' - en position, der er overtaget fra skiftevis det folkerige Egypten, det tidligere militante Saddam-Irak og det olierige SaudiArabien.

$\mathrm{Nu}$ kører tyrkerne med klatten, og hvor syrere for kun et par år siden blev fjerne og fjendtlige i blikket, når de stødte på folk fra den tidligere imperie-magt, er der i dag kindkys og velkomst-kaffe til enhver, der bare ser tyrkiske ud.

Selv en blond og blåøjet kleppert som den i Syrien bosiddende danske forfatter Jesper Berg, der var konferencens primus-motor (med Per Stig Møllers 'arabiske initiativ' som finansielt gulvtæppe), bød velkommen med at fortælle, at han blev 'ta- 
get for tyrker i Damaskus-basaren ‘ Mustafa Kemal Atatürk, den sekulære republiks landsfader, havde som bekendt blå øjne.

Ironisk nok er det stærkt forbedrede forhold til Syrien, senest cementeret med 40 nye samarbejdsaftaler spændende fra turisme til terror-bekæmpelse, fælles militærøvelser, frihandel, ophør af visum-tvangen og etablering af 'strategisk samråd på højt plan', et ledemotiv i AKP-regeringens politiske opgør med Atatürks 'blå øjne', den sekulære politiske arv kaldet kemalismen, hvis mål var 'europæiseringen' af den tyrkiske stat - som Atatürk sagde om den europæiske civilisation: Findes der nogen anden?

\section{Løsrivelse fra Vesten}

Dette opgørs strategiske mål er løsrivelse fra den tilvante tilbedelse af Vesten som rollemodel og skabelsen af en (osmannisk) islamisk statsidentitet.

Arkitekten i denne proces er den mangeårige Erdogan-rådgiver, professor Ahmet Davutoglu, der nu er udenrigsminister, og som på få år har udskiftet den tidligere koldfront til de arabiske naboer med noget, der ligner begyndelsen til et EU-lignende $\varnothing$ konomisk og politisk samarbejde, og som i klassisk spin-stil har kogt strategien ned til et fyndigt slogan: 'Nul problemer med naboer'.

I de otte år, AKP har haft absolut flertal i Nationalforsamlingen, er samhandelen med den arabiske verden og Iran mere end syv-doblet.

Også med Irak, en vigtig handelspartner, er der etableret en strategisk aftale om øget politisk og økonomisk samarbejde i et protokollat med 48 punkter, forholdet til de nordirakiske kurdere er ændret fra skepsis til nærmest venskab med store tyrkiske investeringer i regionens infrastruktur og erhvervsliv.

Palæstinenserne har fået en ny forbundsfælle til et niveau, hvor Hamas-dignitarer modtages på rød løber.

Iran får støtte i atomstriden med Vesten. Erdogan var hurtigt ude i juni med et lykønskningstelegram, da den skrydende præsident Mahmoud Ahmedinejad blev 'genvalgt', og Erdogan veg ikke tilbage fra at kalde ham 'en god ven' ved et statsbesøg til Teheran.

I december undlod Tyrkiet at stemme for, at IAEA, FN's atom-vagthund, der overvåger ikke-spredningsaftalen for atomvåben, sendte Iran-striden videre til FN's sikkerhedsråd med henblik på at stramme sanktionerne.

Endelig, og på mange måder mest opsigtsvækkende, er 'fodbold-diplomatiet', der med præsident Abdullah Güls besøg i Jerevan i foråret 2009 forbindelse med Armeniens VM-kvalifikationsmatch mod Tyrkiet åbnede for den gensidige underskrivelse af to protokoller, der stipulerer diplomatiske forbindelser, kulturelt samarbejde og på sigt genåbning af 
den armensk-tyrkiske grænse, der blev lukket for 17 år siden som følge af konflikten i Ngorno Karabach.

I det øvrige Kaukasus og i Centralasien opererer tyrkerne i ny forståelse (på områder i direkte samarbejde) med Rusland, en stedse vigtigere handelspartner. Projekter i energi-sektoren planlægges, bl.a. den såkaldte Nabucco-ledning, der skal transportere naturgas fra Aserbajdsjan, Turkmenistan, Iran og Irak gennem Tyrkiet til Europa. I dag går forsyningslinjer fra Det Kaspiske Hav, Centralasien og Rusland til Europa bedst og billigst via tyrkisk territorium.

\section{Mødet med Obama}

På den diplomatiske front har Tyrkiet alene i 2009 gennemført 60 statsbesøg - et af dem var Erdogans møde med Barack Obama i Washington i december, hvor det blev gjort klart for amerikanerne, at han talte fra en platform af selvtillid bl.a. ved at kalde samarbejdet med USA for et 'model-partnerskab' - altså lige partnere - i et møde, der varede mere end to timer, og rundede hele spektret fra Cypern til Iran og krigen i Afghanistan, hvor Tyrkiet har 1700 mand udstationeret og en tyrkisk general som NATO-øverstkommanderende.

Men trods de pæne ord var der ikke enighed hele vejen rundt Erdogan lovede at hjælpe med at uddanne det afghanske militær, men var ikke til sinds at sende egentlige kamptropper.

Om Iran sagde han, at Tyrkiet var overbevist om, at landets atomprogram var fredeligt, og at Tyrkiet ville bistå med en udveksling af atombrændsel, som foreslået af IAEA men en egentlig test kommer først, når Tyrkiet som midlertidigt medlem af FN's sikkerhedsråd tager stilling til en eventuel afstemning om nye sanktioner.

\section{Forstyrrende detaljer}

I den 'demokratiske idyl', som den sardonisk blev kaldt af en deltager i Damaskus-konferencen, er forstyrrende detaljer: AKP's brandbeskatning af kritiske medier, den såkaldte Ergenekon-skandale, der med afsæt i militære kupplaner bliver brugt til at eliminere kritiske sekulære røster, det mildt sagt trevne tempo i den EU-inspirerede reformproces, der bortset fra den politiske kontrol med militæret i det store og hele er indstillet, bl.a. er genetablering af de kristne trossamfunds rettigheder stillet på stand by.

Og det tunge emne, demokratiske reformer for kurderne, fik et grundskud kun en uge efter Erdogans USA-optræden, da Tyrkiets forfatningsdomstol med alle 11 dommerstemmer lukkede DTP (Demokratisk Samfunds Parti), det kurdiske parti med en snes deputerede i Nationalforsamlingen.

Begrundelsen var DTP's forbin- 
delser til den forbudte, militante separatist-gruppe PKK (Kurdisk Arbejderparti), hvis leder, den livsvarigt fængslede Abdullah 'Apo' Öcalan, via sine advokater er en reel spiller i tyrkisk-kurdisk politik.

Således blev det stærkt opreklamerede 'kurdiske initiativ', der indtil videre ikke har materialiseret sig i en konkret, sammenhængende politisk plan, skudt i sænk, omend Erdogan med tilkæmpet stædighed fortsat fastholder 'regeringens reform-kurs'.

Men allerede ved lokal-valgene i marts kunne kurdernes utålmodighed aflæses, da DTP tog 99 kommuner og ni provinser på et program, der bl.a. krævede det forbudte PKK inddraget i den annoncerede reformproces.

Efter yderligere et halvt års sniksnak kom Erdogan omsider op med et forslag til en straffelov-ændring, så børn ikke længere kan idømmes fængsel i 30 år for at smide med sten.

Forslaget blev droppet efter at syv soldater blev dræbt i baghold i Tokat i det nordlige Tyrkiet, hvor PKKseparatisterne ikke normalt er aktive, og hvis højst sandsynlige gerningsmænd var fanatikere fra den yderste venstrefløj.

Regeringens øvrige forslag om demokrati og kulturreformer, herunder genetablering af kurdiske stedog bynavne, er forblevet tankespind.

Man kan se forfatningsdomstolens kendelse som 'politisk', vendt mod såvel kurdiske reformer som mod
AKP, der mindre end et år i forvejen med nød og næppe undgik lukning for 'religiøs underminering af den sekulære stat'.

\section{Intet valg}

Men de 11 dommere havde med den nuværende forfatning intet valg: DTP har rent faktisk snore til PKK, som Sinn Fein i Nordirland er relateret til IRA, og Herri Batasuna i Baskerlandet har kontakt til ETA. Og uanset forfatningens dubiøse ophav i 1980-militærkuppet er dens tekst ikke til at misforstå: Anerkendte partier kan ikke pleje omgang med en forbudt organisation, der oven i købet er på Europas og USA's terror-lister.

Der er dem, der ser kendelsen som et skulderklap til AKP's sekulære-nationalistiske opposition, der opmuntrer til etnisk had i en skala, der har medført lynchninger i det vestlige Tyrkiet, bl.a. i Izmir.

Men det er for nemt, som det er for nemt at håne DTP-politikernes følgagtighed over for PKK-chef Öcalan, der styrer pøbel-parlamentet i de kurdiske byer fra sin fængselscelle. DTP blev ladt i stikken af AKP, der ikke evnede at gennemføre reelle politiske reformer i tide, og først reagerede efter lokalvalgene, hvor DTP's fremgang var på AKP's bekostning.

Men da var det for sent og den indre opløsning blev illustreret af gadekampe i kurdiske byer, hvor sik- 
kerhedsstyrker ikke kun efterlod døde og sårede, men også skød reformprocessen i sænk.

\section{Skud til egen fod}

Erdogans tøven, begrundet $\mathrm{i}$ angst for egen skygge og sekulære beskyldninger om plots for at gøre Tyrkiet til et islamisk diktatur, er den grundlæggende årsag til, at Tyrkiet skød sig selv i foden.

Trods opbakning fra mere end 47 pct. af vælgerne, komfortabelt flertal i parlamentet, den renoverede økonomi og støtte fra erhvervsliv og hjemløse socialdemokrater (og EU såmænd), har Erdogan ikke haft politisk mave til at stå imod den forstenede enhedsstats dogmer med praktiske løsninger på det kurdiske problem.

Og så længe det problem eksisterer, vil Tyrkiet fortsat være et spejlbillede af Malatya, hvor frønnet overtro blokerer for et moderne gennembrud - diplomatisk succes eller ej.

Lasse Ellegaard er Informations Mellemфst-korrespondent, stationeret i Beirut. 